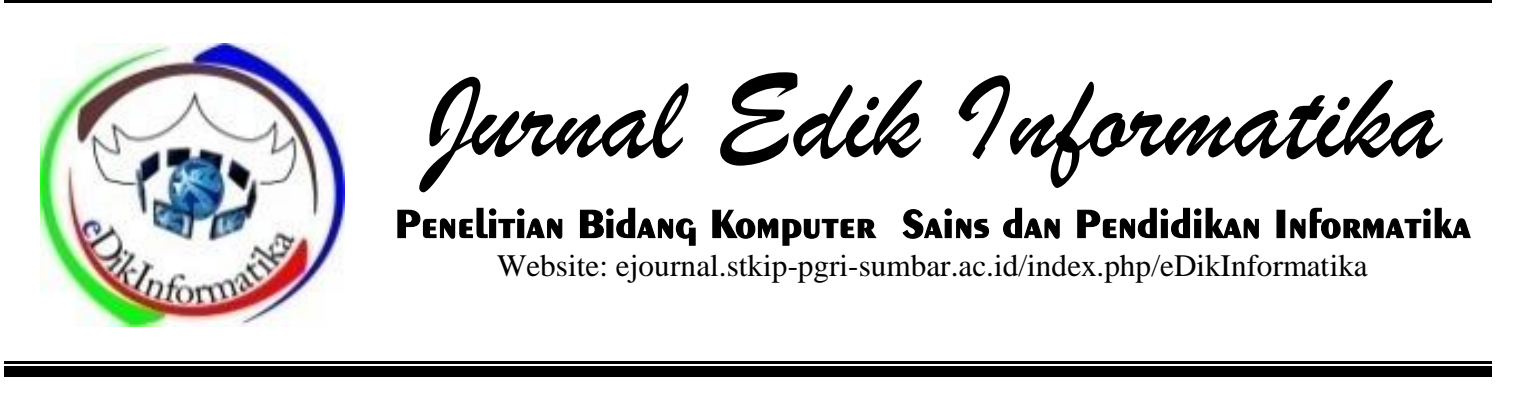

\title{
PERANCANGAN SISTEM E-VOTING UNTUK PEMILIHAN KETUA BEM (BADAN EKSEKUTIF MAHASISWA) DI STKIP PGRI SUMATERA BARAT
}

\author{
Hari Wando ${ }^{1}$, Ade Pratama ${ }^{2}$, Ami Anggraini Samudra ${ }^{3}$ \\ ${ }^{1,2,3}$ STKIP PGRI Sumatera Barat \\ onedomarlis@gmail.com,
}

INFO ARTIKEL

Diterima:

18 Oktober 2019

Direview:

05 November 2019

Disetujui:

26 November 2019

\begin{tabular}{l} 
Keywords: \\
\hline Voting, e-voting, \\
pengembangan sistem, \\
berbasis web.
\end{tabular}

\begin{abstract}
The election of the Student Executive (PilkaBEM) is an inseparable part of the STKIP PGRI Sumatera Barat as a democratic campus. In STKIP PGRI Sumatera Barat PilkaBEM still uses conventional voting, which uses paper media for the voting process. In implementing the conventional pilkaBEM voting system, it has many weaknesses such as requiring a long time for the selection and calculation of ballots, inaccurate ballot calculations and cost a lot. Current advances in information technology have brought huge changes to people, including ways to conduct voting. The use of computer technology in the conduct of voting is known as electronic voting or commonly referred to as e-voting. The research method used in this research is system development, which is an experiment to design e-voting applications using the PHP programming language, HTML tags and to use the MySQL database as a database server. The voting application was developed using web-based system. The e-voting application is in accordance with AD/ART PilkaBEM and is in accordance with the PilkaBEM principles applicable at the STKIP PGRI Sumatera Barat campus. The e-voting application is built using the PHP programming language, and utilizes the MySQL database as a database server. Development of a more attractive appearance without reducing user convenience. As the result, this system has been used, can work properly with positive responses from users and proven by using this system, PilkaBEM uses faster time and saves money.
\end{abstract}

\section{PENDAHULUAN}

Voting digunakan untuk menghimpun aspirasi dari seluruh elemen masyarakat, dan kemudian menemukan jalan keluar yang dianggap paling baik untuk menyelesaikan permasalahan, seperti hakikatnya pemilu dilakukan, dengan aturan yang disepakati dan 
menjadi sebuah peraturan. Seperti perlunya sebagaimana pemungutan surat suara. Semua masalah di atas jadi titik focus bagi panitia penyelenggara pemilihan umum baik skala yang luas seperti pemilihan presiden hingga skala kecil seperti pemilihan ketua BEM (Badan Eksekutif Mahasiswa).

Badan Eksekutif Mahasiswa (BEM) adalah organisasi mahasiswa intra kampus yang merupakan lembaga eksekutif di tingkat Universitas/Institut/Sekolah Tinggi (Pemilihan, Eksekutif, Bem, \& Stmik, 2017). Badan Eksekutif Mahasiswa (BEM) memiliki ketetapan penting dilingkungan Universitas mendapat pendanaan kegiatan kemahasiswaan dari kampus. Tugas pokok BEM adalah mewakili mahasiswa, melaksanakan kegiatan mahasiswa dibidang ekstrakulikuler yang di selengarakan kampus dan memberikan pemikiran, usulan untuk pimpinan kampus berkaitan dengan tugas, fungsi dan pencapaian dari pendidikan.

Saat ini pemilihan BEM (Badan Eksekutif Mahasiswa) di STKIP PGRI Sumatera Barat masih konvensional yaitu menggunakan media kertas suara dan melakukan penghitungan suara secara manual. Kegiatan Pemilihan dan penghitungan surat suara sekarang ini mempunyai beberapa kekurangan, seperti lambatnya proses penghitungan suara pada pemilihan BEM (Badan Eksekutif Mahasiswa) di STKIP PGRI Sumatera Barat, perhitungan suara dapat diulang kembali jika terjadi ketidaksesuaian terhadap hasil perhitungan surat suara. Dan harus mendatangi tempat pemungutan suara pada saat pemilihan menjadi kendala bagi mahasiswa yang sedang melakukan praktek lapangan dan magang industri, sehingga banyak surat suara yang hangus. Selain itu, belum adanya website tentang pemilihan BEM
(Badan Eksekutif Mahasiswa) di STKIP PGRI Sumatera Barat.

Adanya masalah-masalah itu, sehingga dapat sebuah ide untuk melakukan pemilu BEM (Badan Eksekutif Mahasiswa) Pemilu secara elektronik dengan mengunakan teknologi elektronik (e-Voting) sekarang dapat menjadi solusi alternatif untuk menggantikan pemilihan umum konvensional yang sekarang ini digunakan.

Electronic-Voting merupakan salah suatu sistem pemilihan dimana data dicatat, disimpan dan proses dalam informasi digital. Menurut (Risnanto, Studi, Informatika, Teknik, \& Service, 2017), e-Voting adalah suatu metode pemungutan dan penghitungan suara dalam pemilihan dengan menggunakan perangkat elektronik. Dengan kata lain, proses pemungutan surat suara dengan $e$ Voting dilaksanakan secara elektronik (digital) mulai dari pendaftaran pemilih, pelaksanaan pemilihan, perhitungan suara dan pengiriman hasil suara. e-Voting memiliki beberapa kelebihan sepertimudah dalam penghitungan, mudah dalam pelaksanaan pemilihan, mencegah kecuranagan dan mengurangi biaya (Hardjaloka \& Simarmata, 2011).

Dilakukannya analisis pada pemilihan umum makaakan didapatkan dengan suatu perancangan $e$-Voting mengikutsertakan seluruh sumber daya manusia. Sistem dengan kemudahan akses, rendahnya biaya dan juga dapat menjaga data dari manipulasi pihak yang berkepentingan tertentu, diharapkan penghitungan hasil pemilihan dapat lebih cepat dan akurat sehingga segera diketahui hasilnya dengan penggunaan sistem $e$ Voting agar mengurangi kesalahankesalahan pada pemilihan.

\section{METODE PENELITIAN}

Metode penelitian suatu langkah untuk mendapatkan informas dan data yang akan diproses menjadi sistem 
informasi akurat sesuai permasalahan yang akan diteliti. Metode pengumpulan data yang digunakan dalam penelitian ini adalah

\section{Perancangan Sistem dengan Pemodelan UML}

Berfungsi untuk menspesifikasikan, membangun, dan pendokumentasian sebuah sistem perancangan software berbasis OO (Object - Oriented).

\section{a. Use Case Diagram}

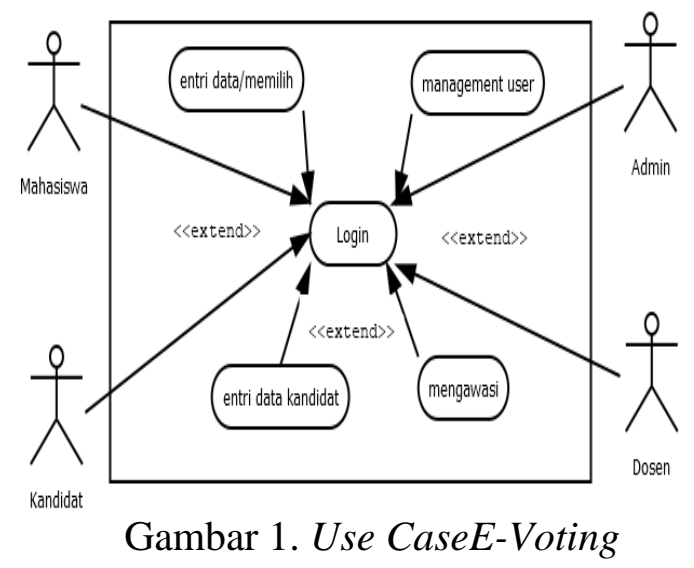

\section{b. Activity Diagram}

\section{Activity Diagram Admin}

Activity diagram Admin menggambarkan setiap aktivitas yang dapat dilakukan oleh Admin dalam sistem $e$-voting yang dapat dilihat pada gambar 2 .

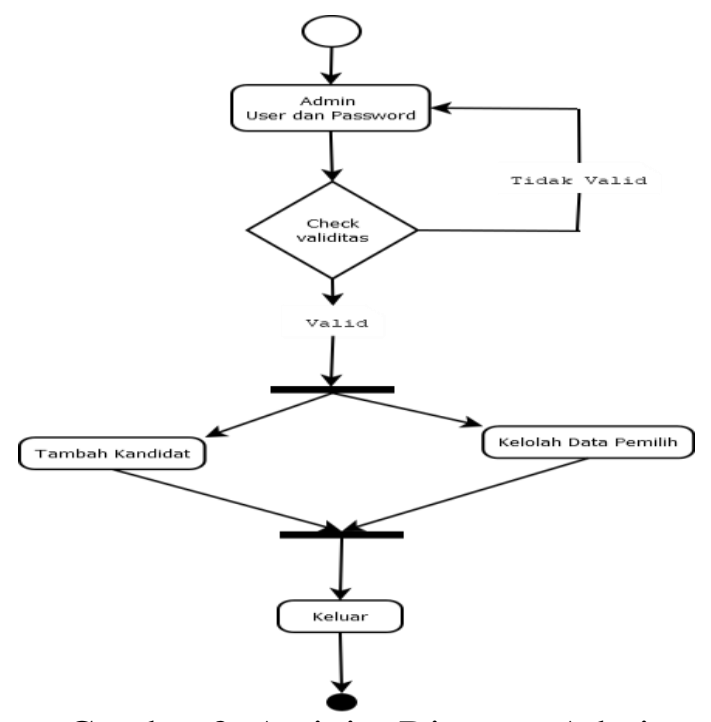

Gambar 2. Activity Diagram Admin c. Sequence diagram

Sequence diagram didesain untuk mengskenrio penyesuaian tahap-tahap yang dilakukan sebagai respons dari sebuah event untuk menghasilan output tertentu.

\section{Sequuence Diagram Voting}

Pada bagian ini menjelaskan bagaimana cara mahasiswa/pemilih masuk, sepert igambar 3:

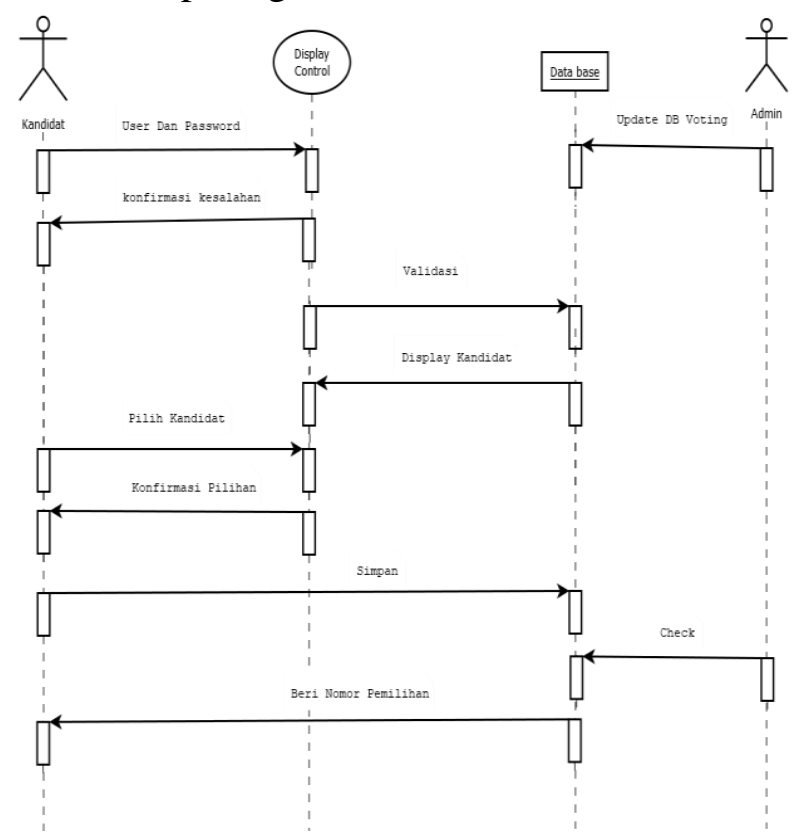

Gambar 3. Sequence Diagram Masuk

\section{Sequence Diagram Kandidat}

Bagian hal ini menjelaskan tentang aktivitas kandidat saat masuk /login pada halaman utama. seperti gambar 4 .

\section{Sequence Diagram Dosen}

Bagian ini menerangkan aktivitas dosen saat melakukan login. Sequence diagram Dosen dapat dilihat pada gambar 5.

\section{d. Class Diagram}

Class Diagram menggambarkan desain database sekaligus hubungan antar table dan field. Class diagram pada system terdapat pada gambar 6 . 


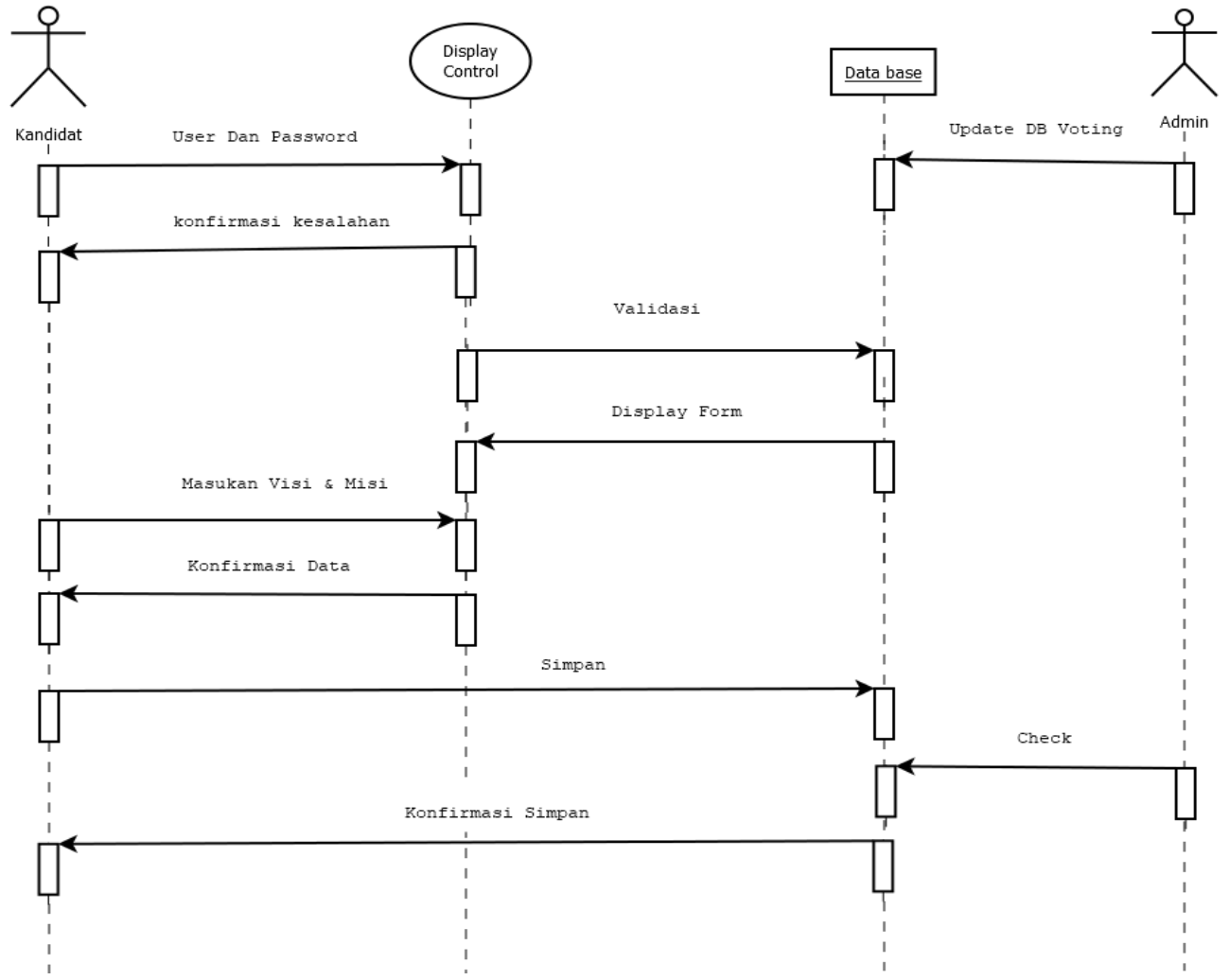

Gambar 4. Sequence Diagram Masuk.

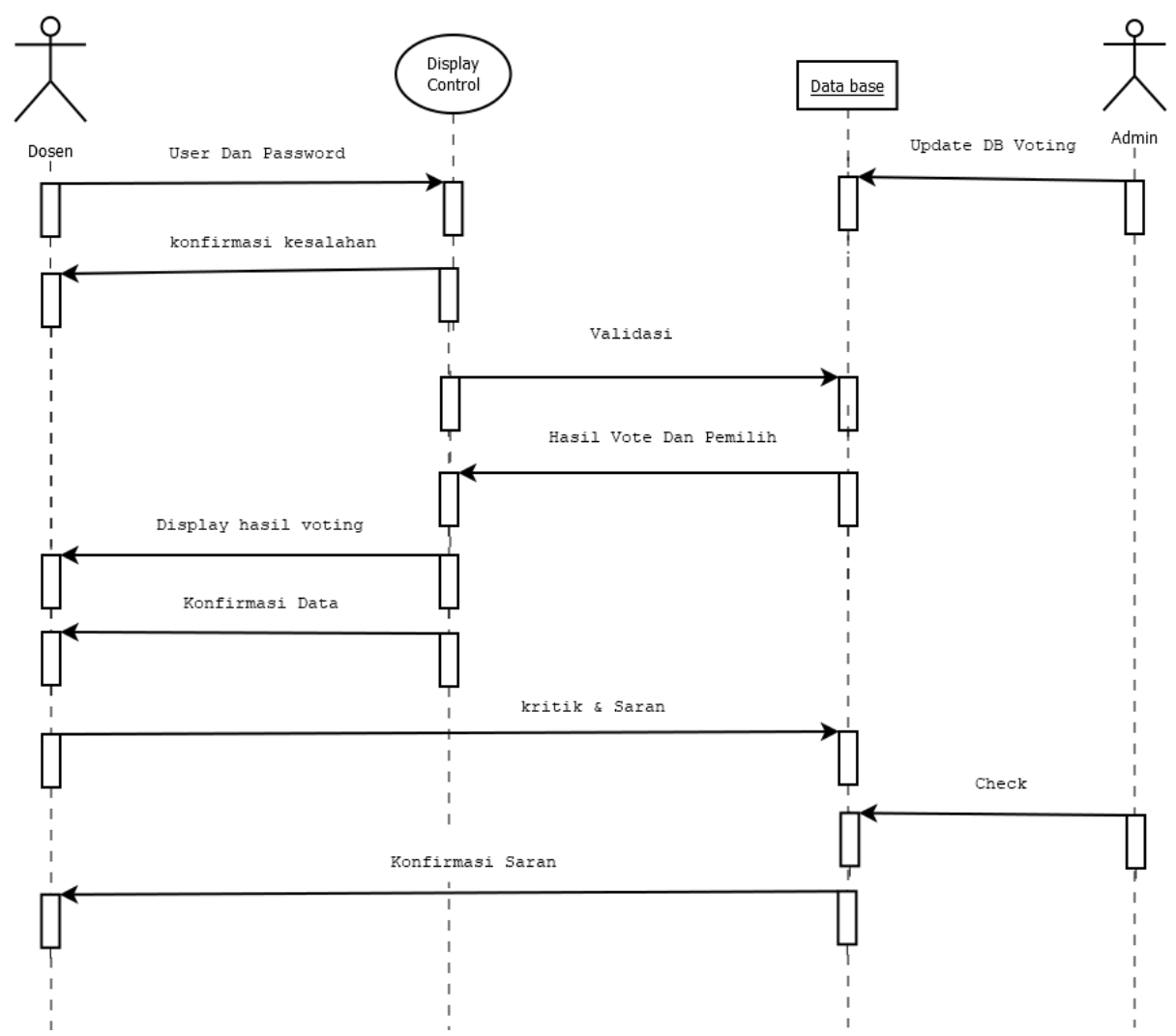

Gambar 5. Sequence Dosen 


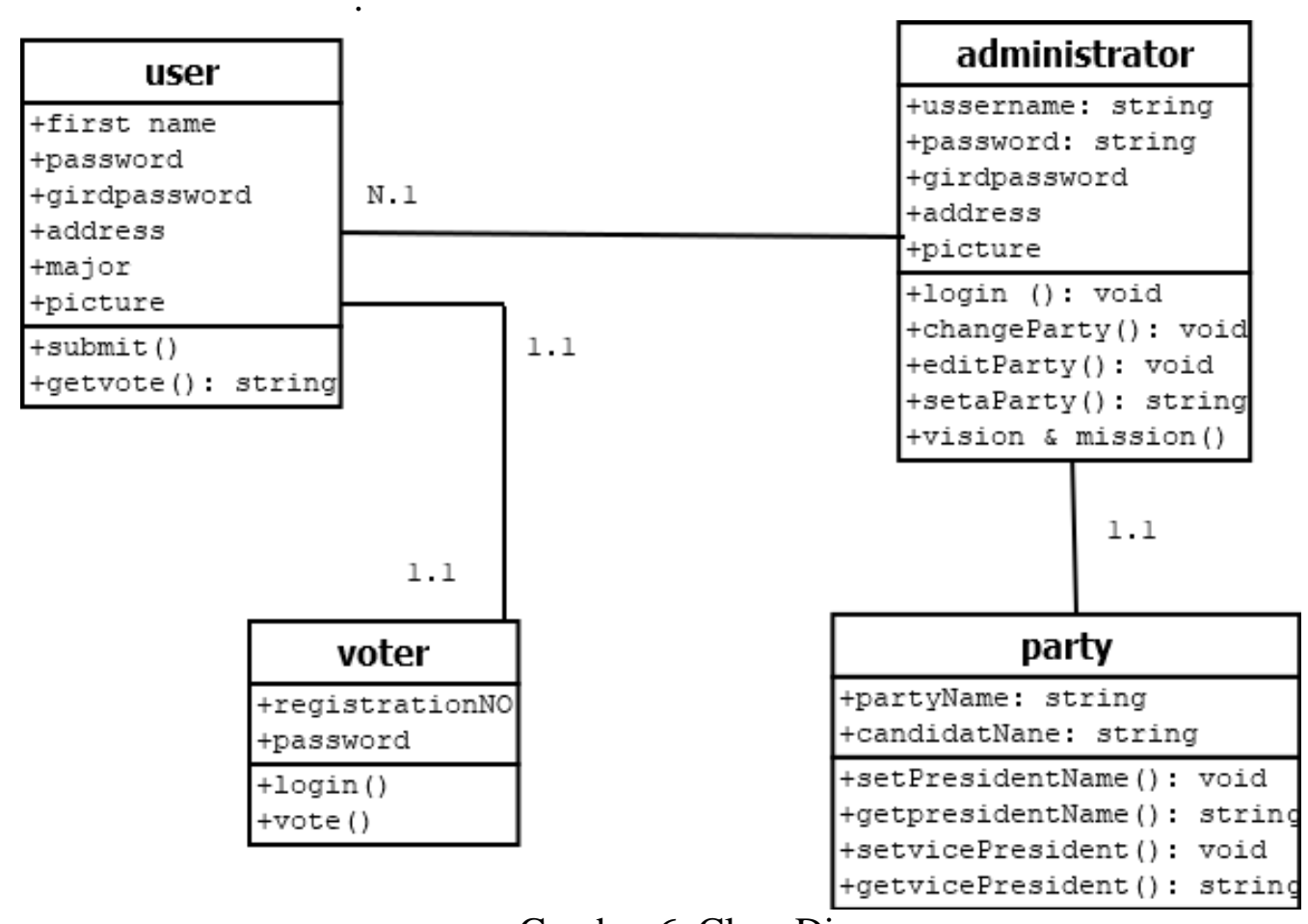

Gambar 6. Class Diagram.

\section{HASIL DAN PEMBAHASAN}

Programe-voting yang sudah dibuat programnya berdasarkan hasil rancangan kemudian dibahas hasil dari program tersebut. Program aplikasi ini dijalankan dengan login ke program sistem $e$ voting. Setelah login maka program dapat dioperasikan berdasarkan aktivitas proses input, dan pengolahan sebagai berikut :

\section{Form Menu Login Admin}

Form login digunakan untuk admin untuk masuk ke halamannya masingmasing tampilan. Tombol Login, digunakan untuk masuk ke menu utama berdasarkan hak aksesnya, dapat dilihat pada gambar 7 .

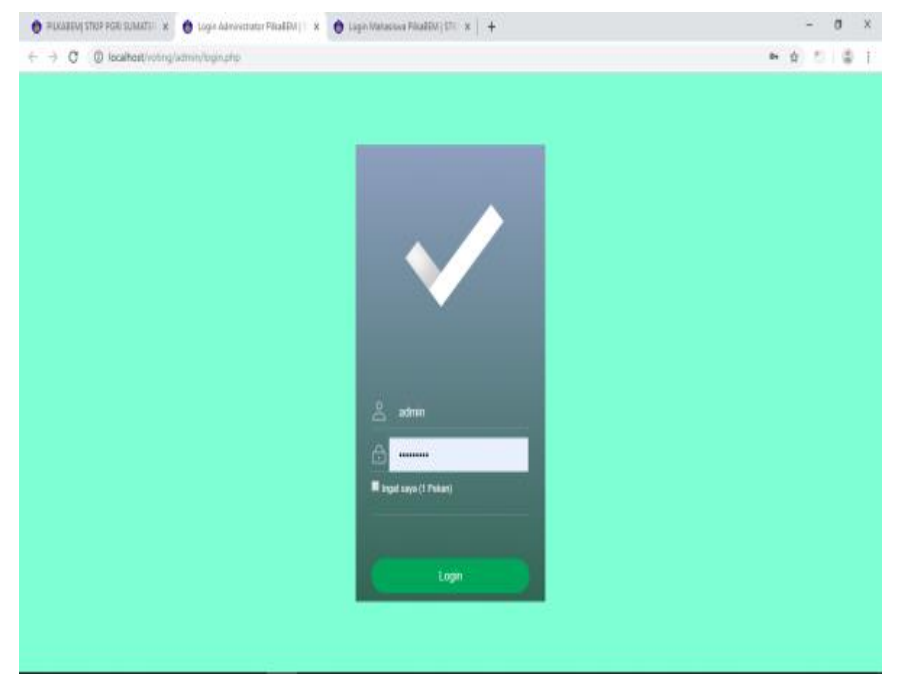




\section{Gambar 7. Halaman Login}

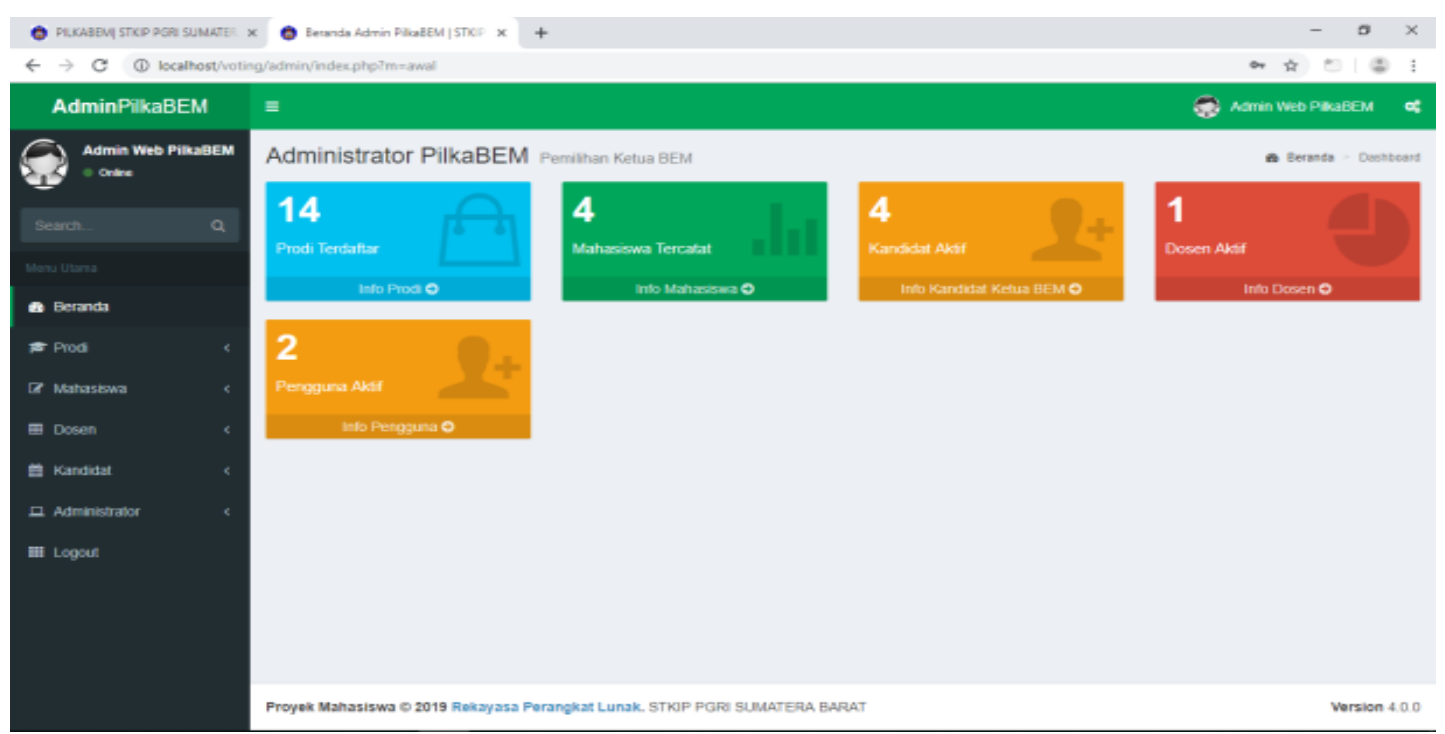

Gambar 8.Form Menu Utama

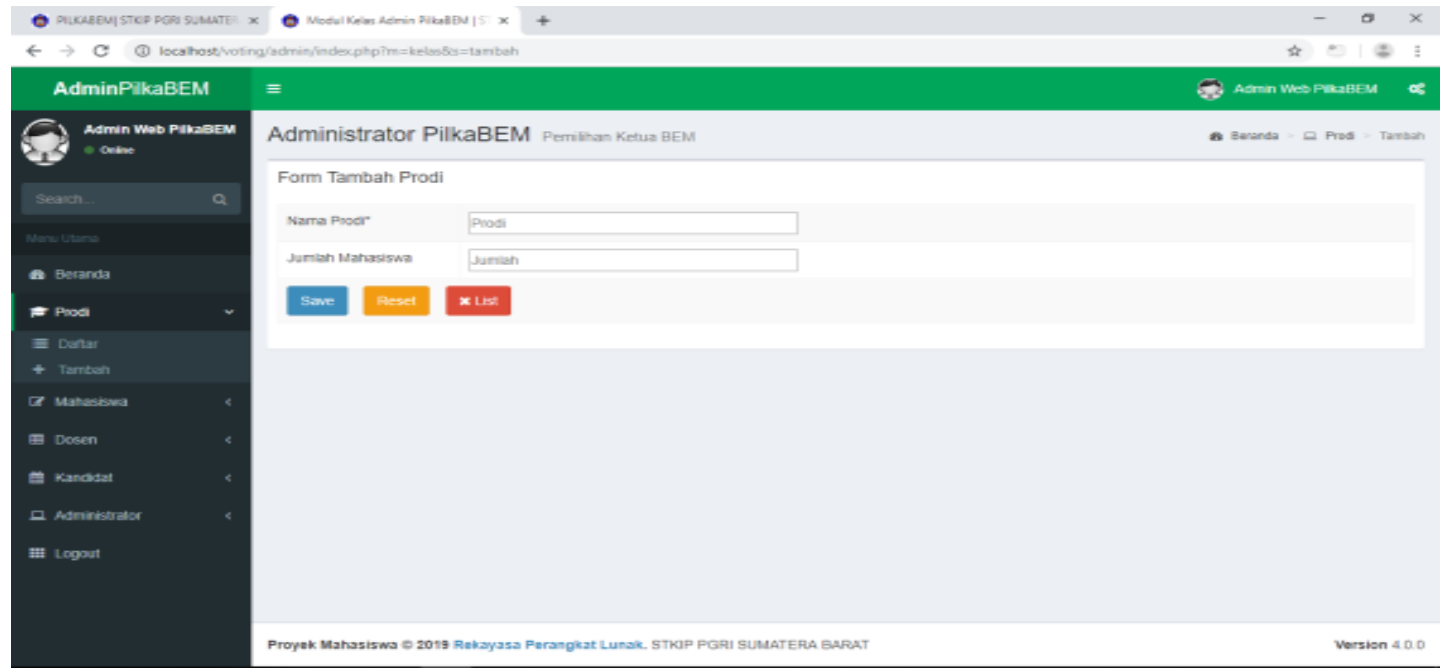

Gambar 9. Form Entri Data Admin

Form Menu Utama

Di menu utama pilihan menu yang terdapat pada menu utama adalah Entri Data, Pencarian Data,dan Logout. (gambar 8)

a. Entri Data terdiri dari entri data admin, mahasiswa, kandidat dan prodi (Program Studi).

b. Pencarian data terdiri dari pencarian data mahasiswa, kandidat.

Form Entry Data Admin
Didalam form entri data admin ini bagian admin dapat mengisi nama admin,untuk penambahan admin baru jika diperlukan. (gambar 9)

a. Tombol save berfungsi untuk menyimpan databarang.

b. Tombol reset berfungsi untuk memperbaharui data.

c. Tombol list berfungsi untuk menghapus data.

Form Entry Data Mahasiswa 
Seperti yang terlihat pada gamabr 10 . Di dalam form entri data Mahasiswaini bagian admin dapat mengisi npm mahasiswa, nama mahasiswa, program studi dan password.

a. Tombol save berfungsi untuk menyimpan data pelanggan.

b. Tombol reset berfungsi untuk memperbaharui data mahasiswa.

c. Tombol list berfungsi untuk menghapus data mahasiswa.

\section{Form Entry Data Dosen}

Didalam formentri (gambar 11) data dosen ini bagian admin dapat mengisi kode dosen, nama dosen, jabatan dosen dan password.

a. Tombol save berfungsi untuk menyimpan data dosen.

b. Tombol reset berfungsi untuk memperbaharui data dosen.

c. Tombol list berfungsi untuk menghapus datadosen

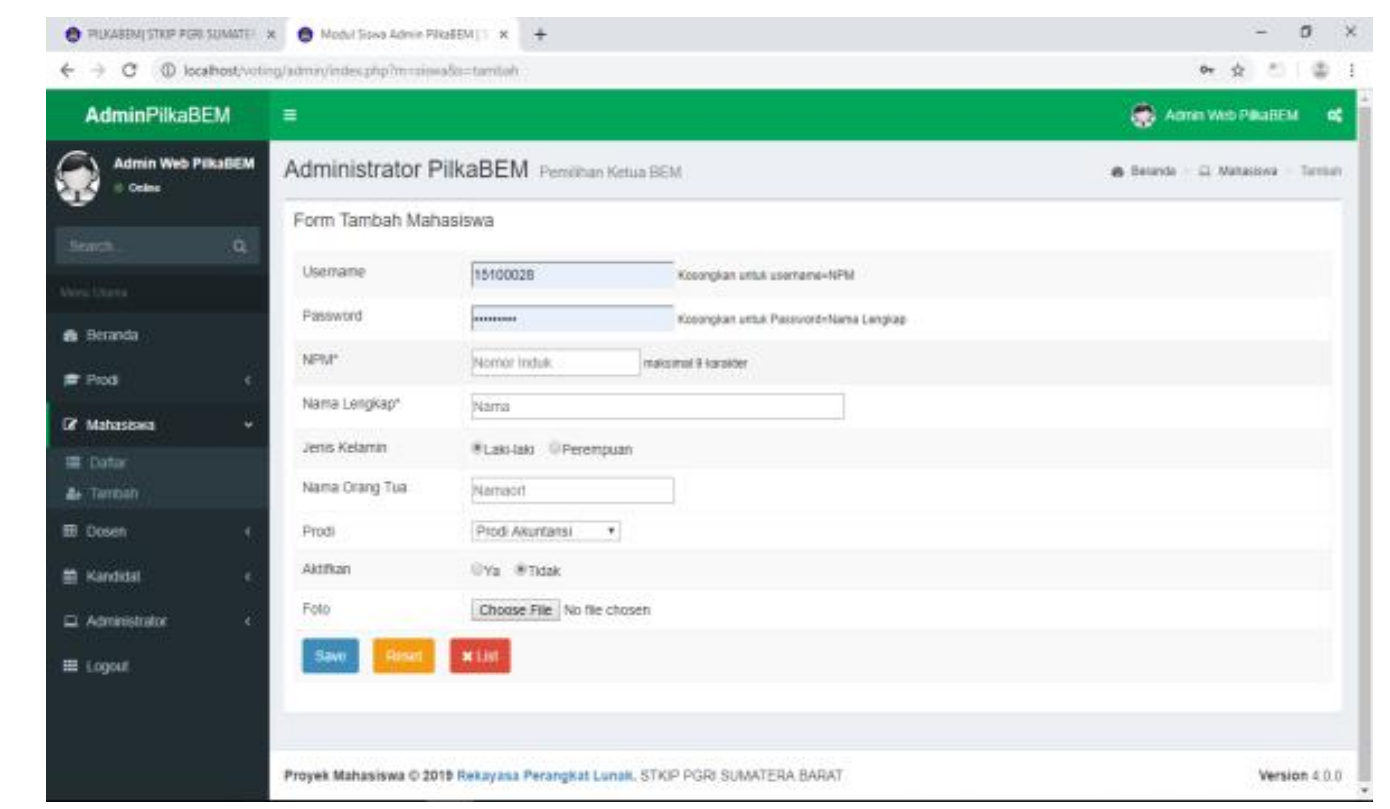

Gambar 10. Form Entri Data Mahasiwa

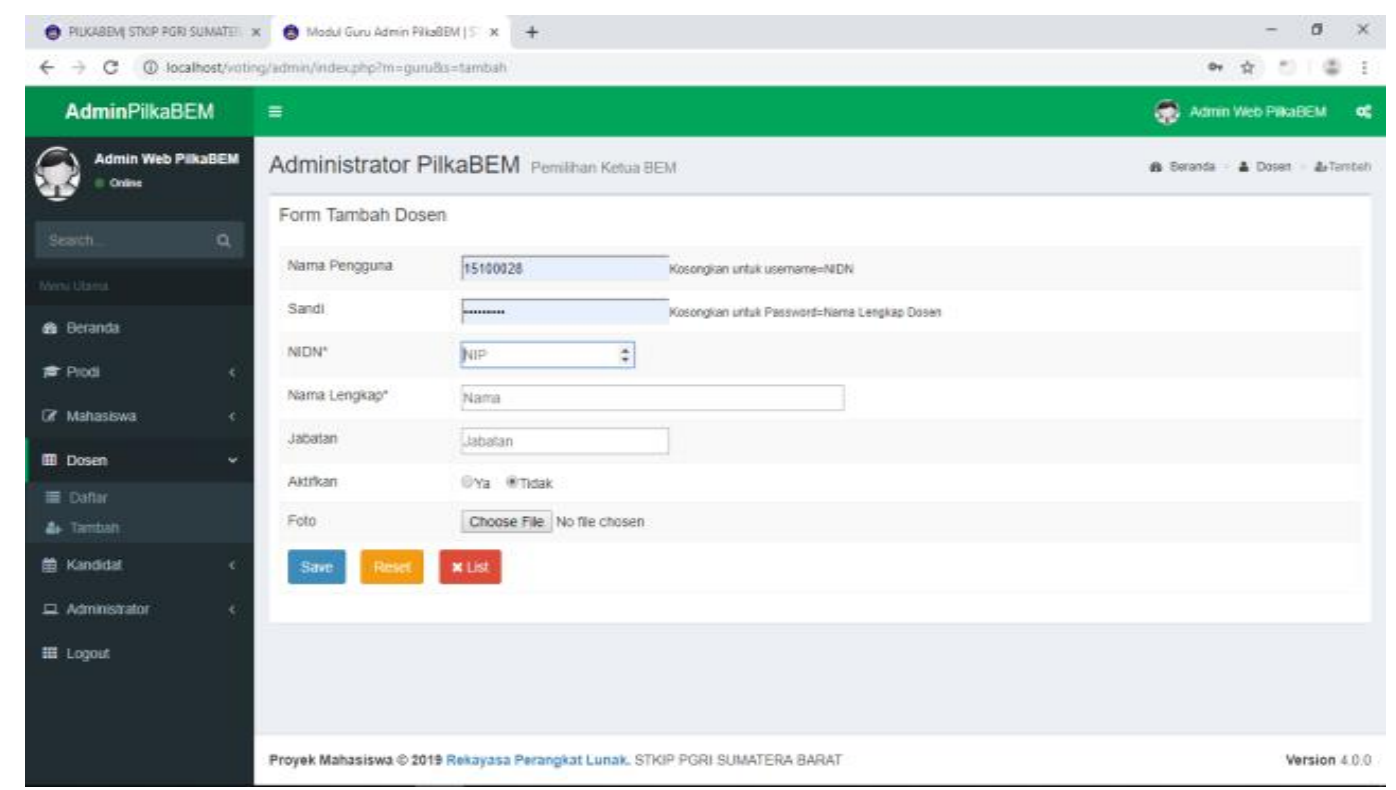

Gambar 11. Form Entri Data Dosen. 


\section{Form Entry Data Kandidat}

Di dalam form entry data kandidat ini (gambar 12) bagian admin dapat mengisi data barang yang akan isi oleh kandidat dan memasukan data seperti visi dan misi dari kandidat.

a. Tombol save berfungsi untuk menyimpan data kandidat.

b. Tombol reset berfungsi untuk memperbaharui data kandidat.

c. Tombol list berfungsi untuk menghapus data kandidat.

\section{Beranda Pemilihan}

Didalam halaman pemilihan mahasiwa yang terdapat pada gambar 13, dapat melihat profil , branda, dan calon kandidat beserta profil kandidat.

a. Menu Beranda, berfungsi untuk pemilihan kandidat yang ingin dipilih.

b. Menu Profil, berfungsi untuk melihat profil dari mahasiswa.

c. Menu Kandidat, berfungsi untuk melihat calon kandidat visi dan misi dari kandidat.

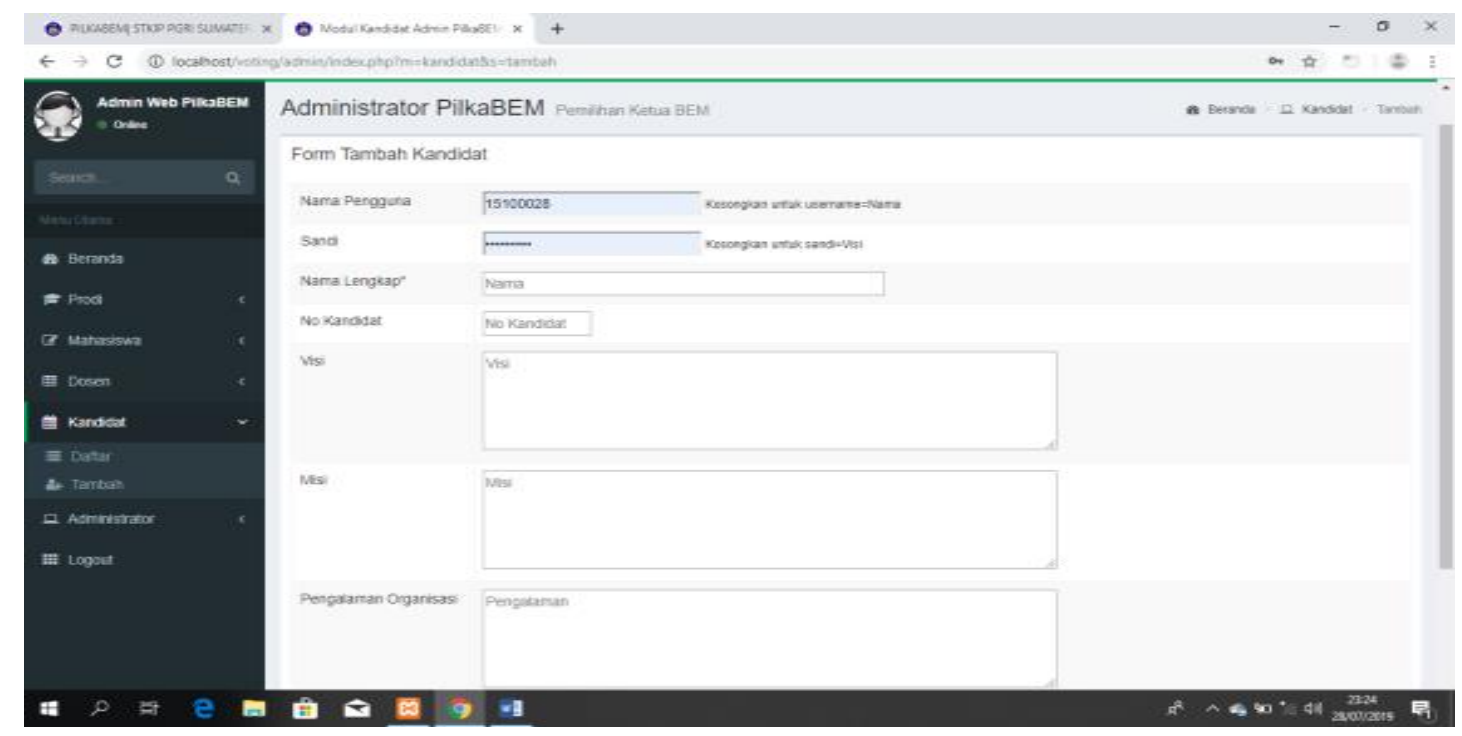

Gambar 12. Form Entri Kandidat.

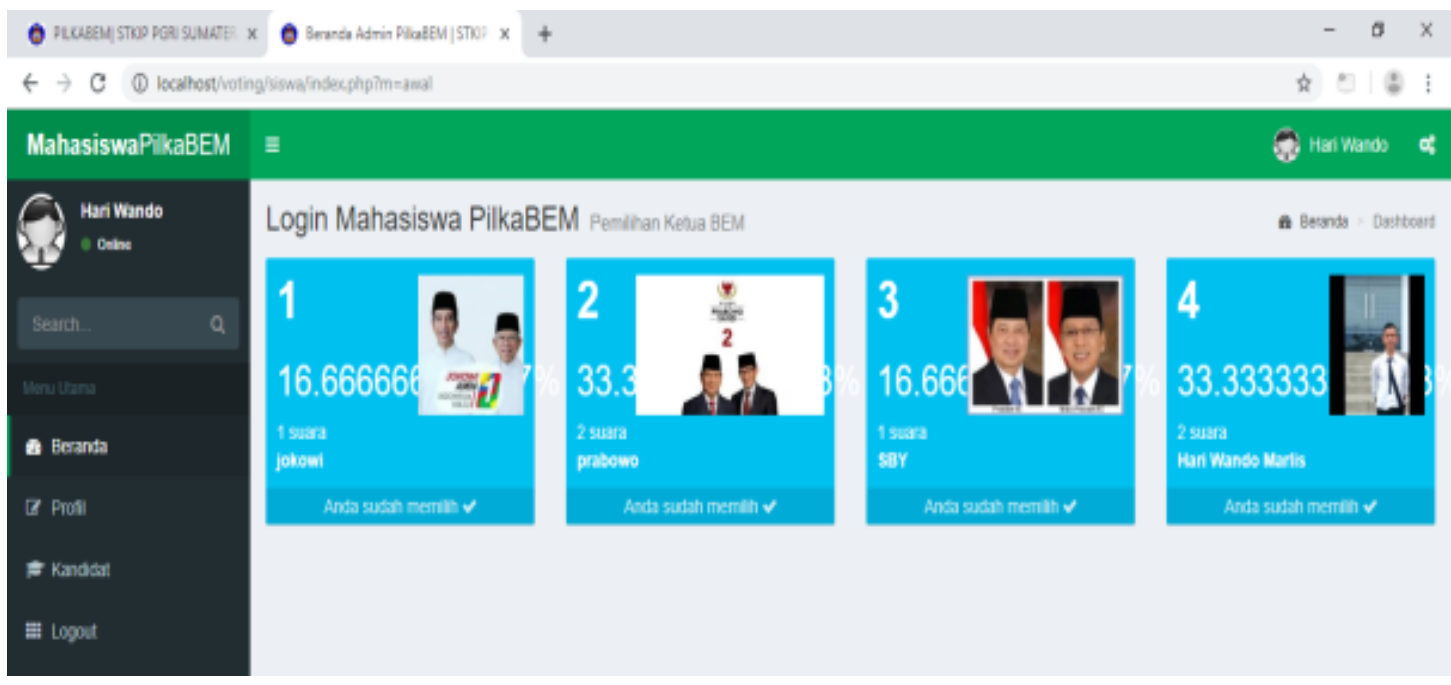

Gambar 13. Tampilan Halaman Pemilihan 


\section{Evaluasi Sistem}

Pada Sistem Informasi E-Voting memiliki kekurangan baik dari segi penyajian laporan. Sistem Informasi $E$ Voting sangat simple dan harus dikembangkan dalam bentuk view dan fungsinya.

\section{Keberlanjutan Sistem}

Pada Sistem Informasi E-Voting ini mungkin masih banyak kekurangan, karena itu Sistem Informasi E-Voting ini masih bisa untuk dikembangkan oleh peneliti selanjutnya dan peneliti selanjutnya juga bisa untuk memperbaiki sistem ini menjadi Sistem Informasi $E$ Voting yang lebih lengkap lagi.

\section{KESIMPULAN}

1. Keuntungan $e$-voting ini pemilihan BEM dapat dilakukan dengan lebih cepat dibandingkan dengan pemilihan secara manual. Pemilihan secara manual membutuhkan waktu untuk pemilihan dan penghitungan suara, jika menggunakan sistem informasie-voting ini memangkas waktu,karena pemilihan dan penghitungan sudah di lakukan oleh sistem terbackup disistem informasi sehingga tidak diperlukan lagi pemilihan ulang.

2. E-voting ini bias melihat antusias pemilih dalam melaksanakan pemlihan ketua dan wakil ketua BEM di STKIP Sumatera Barat.

\section{DAFTAR PUSTAKA}

Pemilihan, S., Eksekutif, B., Bem, M., \& Stmik, D. I. (2017). MUSIRAWAS LUBUKLINGGAU BERBASIS WEB MOBILE DENGAN ENSKRIPSI RSA Zulfauzi Program Studi Teknik Informatika , STMIK Musirawas Email: ozzypramudya@yahoo.co.id. VII(2), 57-63.
Hardjaloka, L., \& Simarmata, V. M. (2011). E-Voting: Kebutuhan vs . Kesiapan ( Menyongson ) EDemokrasi.

Dr. Jogiyanto H.M, M. B. . (2000). Sistem Informasi Berbasis Komputer Konsep Dasar dan Komponen. Yogyakarta: BPFE-Yogyakarta.

Risnanto, S., Studi, P., Informatika, T., Teknik, F., \& Service, S. M. (2017). APLIKASIPEMUNGUTAN SUARA ELEKTRONIK / E-VOTING MENGGUNAKAN. (April), 17-26.

Ir. Hj. Nurmi, M. K. (2016). Konsep Sistem Informasi (2016th ed.; Jafril, ed.). Padang: Sukabima Press. 